\title{
Estimation of Brucella and Mycobacterium bovis contamination in bovine milk in Africa
}

\author{
Nozyechi Ngulube Chidumayo (i)
}

Department of Clinical Studies, University of Zambia, School of Veterinary Medicine, P. O. Box 32379, Lusaka, Zambia. Corresponding author: Nozyechi Ngulube Chidumayo, e-mail: nozyechic@yahoo.com Received: 06-10-2020, Accepted: 19-01-2021, Published online: 26-02-2021

doi: www.doi.org/10.14202/IJOH.2021.37-41 How to cite this article: Chidumayo NN (2021) Estimation of Brucella and Mycobacterium bovis contamination in bovine milk in Africa, Int. J. One Health, 7(1): 37-41.

\begin{abstract}
Background and Aim: Bovine brucellosis and tuberculosis are zoonotic bacterial diseases transmitted through the consumption of raw milk and dairy products. Many developed countries have eliminated bovine brucellosis and tuberculosis in their cattle herds, however, the diseases are still endemic in Africa. Despite the public health risk of these pathogens, the sale and consumption of unpasteurized milk are still common in some African countries. This study aimed to estimate the prevalence of Brucella and Mycobacterium bovis in bovine milk.
\end{abstract}

Materials and Methods: A conceptual model for milk contamination was constructed and 1 million simulations were performed using data from published articles.

Results: Brucella milk contamination was estimated at a median of 8.68\% (interquartile range [IQR]: 5.95-11.97\%; range: 2.41-25.16\%). The median prevalence of $M$. bovis was estimated at $6.86 \%$ (IQR: $4.25-9.40 \%$; range: $0.01-15.16 \%$ ).

Conclusion: These results indicate that there is a risk of Brucella and M. bovis transmission through the consumption of unpasteurized milk. The findings of this study highlight the need to improve the safety and quality of informally marketed milk in the region.

Keywords: Africa, Brucella, cattle, milk, Mycobacterium bovis, zoonoses.

\section{Introduction}

Bovine milk is an important source of dietary protein; however, unpasteurized milk may contain zoonotic pathogens such as Brucella and Mycobacterium [1]. Despite the risk of zoonotic disease transmission, the consumption of raw milk and unpasteurized milk products is still common in some African countries [2-8]. Milk in Africa is marketed through formal and informal milk value chains [5]. The final product in the formal value chain is packed pasteurized milk [5]; however, the safety of milk in the informal value chain is not regulated and consumers are often sold unpasteurized milk $[5,7,9]$. The consumption of raw milk, therefore, poses a health risk in bovine brucellosis and tuberculosis endemic areas.

Brucellosis is a disease caused by intracellular bacteria belonging to the genus Brucella [10]. The disease has public health and economic importance due to its zoonotic nature [11] and negative impact on livestock production [12]. The genus Brucella consists of several species capable of infecting preferred terrestrial and aquatic mammalian hosts [10]. Brucella abortus is associated with brucellosis in cattle $[13,14]$; however, outbreaks of bovine brucellosis

Copyright: Chidumayo. This article is an open access article distributed under the terms of the Creative Commons Attribution 4.0 International License (http://creativecommons.org/licenses/ by/4.0/), which permits unrestricted use, distribution, and reproduction in any medium, provided you give appropriate credit to the original author(s) and the source, provide a link to the Creative Commons license, and indicate if changes were made. The Creative Commons Public Domain Dedication waiver (http:// creativecommons.org/ publicdomain/zero/1.0/) applies to the data made available in this article, unless otherwise stated. due to Brucella melitensis have been reported $[15,16]$. Serological tests such as the Rose Bengal plate test (RBPT) and complement fixation test are commonly used for screening and monitoring brucellosis in cattle [17], although, not all seropositive animals have active infections [18]. The bacteria have also been isolated from the milk of seronegative cows [17-19].

Bovine tuberculosis is a zoonotic bacterial disease caused by Mycobacterium bovis, a member of Mycobacterium tuberculosis complex [4]. Bovine tuberculosis is of economic importance due to post-slaughter carcasses condemnation [20,21]. The bacteria are transmitted to humans through the consumption of raw milk, but not all infected cows shed the bacteria in milk [22-24]. The single intradermal comparative cervical tuberculin (SICCT) test is commonly used to identify cattle infected with $M$. bovis; however, not all infected cattle are detected using this test $[25,26]$.

This study aimed to estimate the prevalence of Brucella and M. bovis in milk in Africa. This was the secondary study and all the data used for the analysis were based on published articles. The findings of this study highlight the public health significance of raw milk consumption and the need to improve the safety and quality of milk in Africa.

\section{Materials and Methods \\ Ethical approval}

Ethical approval was not required for this study.

\section{Conceptual model}

The prevalence of bacterial milk contamination was calculated based on six parameters: The prevalence 
of test positive females (P1); the proportion of lactating cows among the test positive females (P2); the probability of a test positive lactating cow shedding the bacteria in the milk (P3); the prevalence of test negative females (P4=1-P1); the proportion of lactating cows among the test negative females (P5); and the probability of a test negative lactating cow shedding the bacteria in the milk (P6). The probability of contaminated milk from a seropositive and seronegative female is $\mathrm{P} 7(\mathrm{P} 7=\mathrm{P} 1 \times \mathrm{P} 2 \times \mathrm{P} 3)$ and $\mathrm{P} 8(\mathrm{P} 8=\mathrm{P} 4 \times \mathrm{P} 5 \times \mathrm{P} 6)$, respectively. The prevalence of contaminated milk is the sum of $\mathrm{P} 7$ and $\mathrm{P} 8$; divided by the probability of lactating females $([\mathrm{P} 1 \times \mathrm{P} 2]+[\mathrm{P} 4 \times \mathrm{P} 5])$.

The parametervalues for the estimation of Brucella milk contamination are shown in Table-1 [3,18,27-38]. The secretion probability was based on bacteria culture results of milk collected from RBPT seropositive and seronegative cattle [18]. The female prevalence was based on RBPT results from five African countries; Egypt [27], Ethiopia [28,29], Nigeria [30,31], Tanzania [32], and Sudan [33,34]. One million probability values for P1, P2, and P5 were randomly generated based on uniform distributions of the values in Table-1. Ersatz version 1.35 (EpiGear International, www.epigear.com) was used to randomly generate the parameter values. All the calculations were performed in Microsoft Excel. The results were reported as median, interquartile range (IQR), and range.

The parameter values for the estimation of M. bovis milk contamination are shown in Table-2. The secretion probability was based on bacteria culture results of milk from SICCT test negative and positive cows. The female prevalence was based on SICCT test results from five African countries; Nigeria [39], Mozambique [40], Uganda [41], Tanzania [42], and Ethiopia $[43,44]$. One million values for each parameter were randomly generated based on uniform distributions of the values in Table-2 [22-24,39-46].

\section{Results}

Brucella milk contamination was estimated at a median of $8.68 \%$ (IQR: $5.95-11.97 \%$; range:

Table-1: Model parameter values for the estimation of Brucella milk contamination.

\begin{tabular}{lcc}
\hline Parameter & Values & References \\
\hline P1 & $0.042-0.307$ & {$[27-34]$} \\
P2 & $0.196-0.545$ & {$[3,35-38]$} \\
P3 & 0.458 & {$[18]$} \\
P5 & $0.212-0.588$ & {$[3,35-38]$} \\
P6 & 0.018 & {$[18]$} \\
\hline
\end{tabular}

Table-2: Model parameter values for the estimation of Mycobacterium bovis milk contamination.

\begin{tabular}{lcc}
\hline Parameter & Values & References \\
\hline P1 & $0.004-0.335$ & {$[39-44]$} \\
P2 & $0.333-0.620$ & {$[42,43,45]$} \\
P3 & $0-0.188$ & {$[22-24]$} \\
P5 & $0.362-0.542$ & {$[42,43,45]$} \\
P6 & $0-0.125$ & {$[22,46]$} \\
\hline
\end{tabular}

$2.41-25.16 \%$ ). Milk contamination of $<5 \%$ prevalence occurred in $7.12 \%$ of the simulations. Only $2.13 \%$ of the simulations had $\geq 20 \%$ prevalence.

The median prevalence of $M$. bovis was estimated at 6.86\% (IQR: 4.25-9.40\%; range: 0.01-15.16\%). Only $4.24 \%$ of the simulations had $\geq 12 \%$ prevalence.

\section{Discussion}

One million simulations were performed to estimate the prevalence of Brucella and M. bovis in individual cow milk samples. The results indicate that Brucella milk contamination in Africa is unlikely to exceed 20\%. The estimated Brucella prevalence corresponds with the $4.7 \%$ and $5.3 \%$ prevalence reported in Bangladesh [18] and Uganda [47], respectively. Other studies in Africa have reported higher prevalences of $38.1 \%$ in Nigeria [48] and $29 \%$ in Uganda [49]; however, the milk contamination in these studies was based on the detection of Brucella antibodies and not the isolation of the bacteria, which may overestimate the prevalence [50].

M. bovis milk contamination was estimated at $0.01-15.16 \%$ but the results indicate that the prevalence is unlikely to exceed $12 \%$. Several authors have reported the prevalence of $M$. bovis in milk in Africa; however, their results were based on the isolation of the bacteria from tuberculin reactors [51-53]. The reported bacterial contamination may have been underestimated since positive milk from false-negative cows was excluded. There are limited studies investigating the prevalence of $M$. bovis in the milk of tuberculin negative cows in Africa; however, a study conducted in Tanzania detected $M$. bovis genetic material from non-reactor lactating cows [54]. Falsenegative cows may, therefore, play an important role in the epidemiology of bovine tuberculosis in the region.

Although this study focused on the estimation of $M$. bovis milk contamination, other members of the genus Mycobacterium such as M. tuberculosis, Mycobacterium africanum, and non-tuberculosis mycobacteria (NTM) have been isolated from bovine milk [55-58]. M. tuberculosis and M. africanum are both members of $M$. tuberculosis complex and cause infections in humans $[59,60]$. The presence of these bacteria in bovine milk poses a potential public health risk. The public health significance of NTM in milk is not well defined but the bacteria are considered emerging causes of infections in humans [61-63].

A limitation of this study is that it only considers the possibility of milk contamination from individual cows which may underestimate the risk of human exposure through milk consumption. One shedding cow may contaminate the farm bulk milk when the milk from several cows is pooled [64]. The risk of bulk milk contamination at farm level has been reported for several milk-borne pathogens including M. bovis [64] and Listeria monocytogenes $[65,66]$. 


\section{Conclusion}

The findings of this study highlight the public health significance of bovine brucellosis and tuberculosis in Africa. The quality and safety of milk, particularly in the informal value chain, needs to be improved to reduce the risk of zoonotic disease transmission. Further studies are required to investigate the role of false-negative cattle in the epidemiology of these diseases.

\section{Author's Contributions}

NNC designed the study, analyzed the data, drafted, reviewed and approved the manuscript.

\section{Acknowledgments} study.

The authors did not receive any funds for this

\section{Competing Interests} interests.

The author declares that she has no competing

\section{Publisher's Note}

Veterinary World (Publisher of International Journal of One Health) remains neutral with regard to jurisdictional claims in published institutional affiliation.

\section{References}

1. Akbarmehr, J. (2011) The prevalence of Brucella abortus and Brucella melitensis in local cheese produced in Sarab city, Iran and its public health implication. Afr. J. Microbiol. Res., 5(12): 1500-1503.

2. Amenu, K., Wieland, B., Szonyi, B. and Grace, D. (2019) Milk handling practices and consumption behavior among Borana pastoralists in Southern Ethiopia. J. Health Popul. Nutr., 38(1): 6.

3. Chaka, H., Aboset, G., Garoma, A., Gumi, B. and Thys, E. (2018) Cross-sectional survey of brucellosis and associated risk factors in the livestock-wildlife interface area of Nechisar National Park, Ethiopia. Trop. Anim. Health Prod., 50(5): 1041-1049.

4. Biru, A., Ameni, G., S ori, T., Desissa, F., Teklu, A. and Tafess, K. (2014) Epidemiology and public health significance of bovine tuberculosis in and around Sululta District, Central Ethiopia. Afr. J. Microbiol. Res., 8(24): 2352-2358.

5. Makita, K., Desissa, F., Teklu, A., Zewde, G. and Grace, D. (2012) Risk assessment of staphylococcal poisoning due to consumption of informally-marketed milk and home-made yoghurt in Debre Zeit, Ethiopia. Int. J. Food Microbiol., 153(1-2): 135-141.

6. Tolosa, T., Verbeke, J., Piepers, S., Tefera, M., Getachew, Y., Supré, K. and DeVliegher, S. (2016) Milk production, quality, and consumption in Jimma (Ethiopia): Facts and producers retailers, and consumers' perspectives. Prev. Vet. Med., 124: 9-14.

7. Kouamé-Sina, S.M., Makita, K., Costard, S., Grace, D., Dadié, A., Dje, M. and Bonfoh, B. (2012) Hazard identification and exposure assessment for bacterial risk assessment of informally marketed milk in Abidjan, Côte d'Ivoire. Food Nutr. Bull., 33(4): 223-234.

8. Tumwine, G., Matovu, E., Kabasa, J.D., Owiny, D.O. and Majalija, S. (2015) Human brucellosis: Sero-prevalence and associated risk factors in agro-pastoral communities of Kiboga District, Central Uganda. BMC Public Health, $15: 900$.
9. Makita, K., Fèvre, E.M., Waiswa, C., Eisler, M.C. and Welburn, S.C. (2010) How human brucellosis incidence in urban Kampala can be reduced most efficiently? A stochastic risk assessment of informally-marketed milk. PLoS One, 5(12): e14188.

10. Nymo, I.H., Tryland, M. and Godfroid, J. (2011) A review of Brucella infection in marine mammals, with special emphasis on Brucella pinnipedialis in the hooded seal (Cystophora cristata). Vet. Res., 42(1): 93.

11. Dean, A.S., Crump, L., Greter, H., Schelling, E. and Zinsstag, J. (2012) Global burden of human brucellosis: A systematic review of disease frequency. PLoS Negl. Trop. Dis., 6(10): e1865.

12. Mangen, M., Otte, J., Pfeiffer, D. and Chilonda, P. (2002) Bovine Brucellosis in Sub-Saharan Africa: Estimation of Sero-prevalence and Impact on Meat and Milk Offtake Potential. FAO Livestock Policy Discussion Paper No, 8. Available from: http://www.fao.org/ag/againfo/resources/ es/publications/sector_discuss/pp8.pdf. Retrieved on 13 12-2018

13. Aparicio, E.D. (2013) Epidemiology of brucellosis in domestic animals caused by Brucella melitensis, Brucella suis and Brucella abortus. Rev. Sci. Tech., 32(1): 53-60.

14. Poester, F., Samartino, L. and Santos, R. (2013) Pathogenesis and pathobiology of brucellosis in livestock. Rev. Sci. Tech., 32(1): 105-115.

15. Álvarez, J., Sáez, J.L., García, N., Serrat, C., PérezSancho, M., González, S., Ortega, M.J., Gou, J., Carbajo, L. and Garrido, F. (2011) Management of an outbreak of brucellosis due to B. melitensis in dairy cattle in Spain. Res. Vet. Sci., 90(2): 208-211.

16. van Straten, M., Bardenstein, S., Keningswald, G. and Banai, M. (2016) Brucella abortus S19 vaccine protects dairy cattle against natural infection with Brucella melitensis. Vaccine, 34(48): 5837-5839.

17. Mailles, A., Rautureau, S., Le Horgne, J., Poignet-Leroux, B., d'Arnoux, C., Dennetière, G., Faure, M., Lavigne, J., Bru, J. and Garin-Bastuji, B. (2012) Re-emergence of brucellosis in cattle in France and risk for human health. Euro Surveill., 17(30): 20227.

18. Islam, M., Khatun, M., Saha, S., Basir, M. and Hasan, M.M. (2018) Molecular detection of Brucella spp. from milk of seronegative cows from some selected area in Bangladesh. J. Pathog., 2018: 9378976.

19. Zowghi, E., Ebadi, A. and Mohseni, B. (1990) Isolation of Brucella organisms from the milk of seronegative cows. Rev. Sci. Tech., 9(4): 1175-1178.

20. Ejeh, E., Raji, M., Bello, M., Lawan, F., Francis, M., Kudi, A. and Cadmus, S. (2014) Prevalence and direct economic losses from bovine tuberculosis in Makurdi, Nigeria. Vet. Med. Int., 2014: 904861.

21. Yibar, A., Selcuk, O. and Senlik, B. (2015) Major causes of organ/carcass condemnation and financial loss estimation in animals slaughtered at two abattoirs in Bursa Province, Turkey. Prev. Vet. Med., 118(1): 28-35.

22. Jayasumana, M., Galappaththi, T., Pushpakumara, P., Gamage, C., Smith, N. and Jinadasa, H. (2018) Screening milk for bovine tuberculosis in dairy farms in Central Province, Sri Lanka. Trop. Agric. Res., 30(1): 12-18.

23. Pandey, G.S., Hang'ombe, B.M., Mushabati, F. and Kataba, A. (2013) Prevalence of tuberculosis among southern Zambian cattle and isolation of Mycobacterium bovis in raw milk obtained from tuberculin positive cows. Vet. World, 6(12): 986-991.

24. Ramos, J.M., Heinemann, M.B., Neto, J.S.F., Cárdenas, N.C., Alves, C.J. and Azevedo, S.S.D. (2016) Isolation and identification of Mycobacterium bovis in milk from cows in Northeastern Brazil. Cienc. Rural., 46(12): 2166-2169.

25. Whelan, C., Shuralev, E., Kwok, H.F., Kenny, K., Duignan, A., Good, M., Davis, W.C. and Clarke, J. (2011) Use of a multiplex enzyme-linked immunosorbent assay to 
detect a subpopulation of Mycobacterium bovis-infected animals deemed negative or inconclusive by the single intradermal comparative tuberculin skin test. J. Vet. Diagn. Invest., 23(3): 499-503.

26. Lahuerta-Marin, A., McNair, J., Skuce, R., McBride, S., Allen, M., Strain, S.A., Menzies, F.D., McDowell, S.J. and Byrne, A.W. (2016) Risk factors for failure to detect bovine tuberculosis in cattle from infected herds across Northern Ireland (2004-2010). Res. Vet. Sci., 107: 233-239.

27. El-Hady, A., Ahmed, M., Saleh, M. and Younis, E. (2016) Seroprevalence and molecular epidemiology of brucellosis in cattle in Egypt. J. Adv. Dairy Res., 4(2): 153.

28. Tesfaye, G., Wondimu, A., Asebe, G., Rogasa, E. and Mamo, G. (2017) Sero-prevalence of bovine Brucellosis in and around Kombolcha, Amhara Regional State, Ethiopia. Mycobact. Dis., 7(2): 242.

29. Dinka, H. and Chala, R. (2009) Seroprevalence study of bovine brucellosis in pastoral and agro-pastoral areas of East Showa Zone, Oromia Regional State, Ethiopia. $J$. Agric. Environ. Sci., 6(5): 508-512.

30. Ogugua, A.J., Akinseye, V.O., Cadmus, E.O., Awosanya, E.A.J., Alabi, P.I., Idowu, O.S., Akinade, S.A., Dale, E.J., Perrett, L. and Taylor, A. (2018) Prevalence and risk factors associated with bovine brucellosis in herds under extensive production system in Southwestern Nigeria. Trop. Anim. Health Prod., 50(7): 1573-1582.

31. Adamu, S., Kabir, J., Umoh, J. and Raji, M. (2018) Seroprevalence of brucellosis and Q fever (Coxiellosis) in cattle herds in Maigana and Birnin Gwari agro-ecological zone of Kaduna State, Nigeria. Trop. Anim. Health Prod., 50(7): 1583-1589.

32. Chitupila, G., Komba, E. and Mtui-Malamsha, N. (2015) Epidemiological study of bovine brucellosis in indigenous cattle population in Kibondo and Kakonko Districts, Western Tanzania. Livest. Res. Rural. Dev., 27(6): 118.

33. Ebrahim, W.O.M., Elfadil, A.A.M. and Elgadal, A.A. (2016) Seroprevalence and risk factors of anti-brucella antibodies in cattle in Khartoum State, the Sudan. J. Adv. Vet. Anim. Res., 3(2): 134-144.

34. Madut, N.A., Muwonge, A., Nasinyama, G.W., Muma, J.B., Godfroid, J., Jubara, A.S., Muleme, J. and Kankya, C. (2018) The sero-prevalence of brucellosis in cattle and their herders in Bahr el Ghazal region, South Sudan. PLoS Negl. Trop. Dis., 12(6): e0006456.

35. Haileselassie, M., Kalayou, S., Kyule, M., Asfaha, M. and Belihu, K. (2011) Effect of Brucella infection on reproduction conditions of female breeding cattle and its public health significance in Western Tigray, Northern Ethiopia. Vet. Med. Int., 2011: 354943.

36. Tsegaye, Y., Kyule, M. and Lobago, F. (2016) Seroprevalence and risk factors of bovine brucellosis in Arsi Zone, Oromia Regional State, Ethiopia. Am. Sci. Res. J. Eng. Tech. Sci., 24(1): 16-25.

37. Terefe, Y., Girma, S., Mekonnen, N. and Asrade, B. (2017) Brucellosis and associated risk factors in dairy cattle of Eastern Ethiopia. Trop. Anim. Health Prod., 49(3): 599-606.

38. Adugna, K., Agga, G. and Zewde, G. (2013) Seroepidemiological survey of bovine brucellosis in cattle under a traditional production system in Western Ethiopia. Rev. Sci. Tech., 32(3): 765-773.

39. Ibrahim, S., Agada, C.A., Umoh, J.U., Ajogi, I., Farouk, U.M. and Cadmus, S.I. (2010) Prevalence of bovine tuberculosis in Jigawa State, Northwestern Nigeria. Trop. Anim. Health Prod., 42(7): 1333-1335.

40. Moiane, I., Machado, A., Santos, N., Nhambir, A., Inlamea, O., Hattendorf, J., Kallenius, G., Zinsstag, J. and Correia-Neves, M. (2014) Prevalence of bovine tuberculosis and risk factor assessment in cattle in rural livestock areas of Govuro District in the Southeast of Mozambique. PLoS One, 9(3): e91527.

41. Kazoora, H.B., Majalija, S., Kiwanuka, N. and Kaneene, J.B (2014) Prevalence of Mycobacterium bovis skin positivity and associated risk factors in cattle from western Uganda. Trop. Anim. Health Prod., 46(8): 1383-1390.

42. Kazwala, R.R., Kambarage, D.M., Daborn, C.J., Nyange, J., Jiwa, S.F. and Sharp, J.M. (2001) Risk factors associated with the occurrence of bovine tuberculosis in cattle in the Southern highlands of Tanzania. Vet. Res. Commun., 25(8): 609-614.

43. Endalew, M. and Chimdi, B. (2017) Bovine tuberculosis prevalence, potential risk factors and its public health implication in selected state dairy farms, Central Ethiopia. World Vet. J., 7(1): 21-29.

44. Mekonnen, G.A., Conlan, A.J., Berg, S., Ayele, B.T., Alemu, A., Guta, S., Lakew, M., Tadesse, B., Gebre, S. and Wood, J.L. (2019) Prevalence of bovine tuberculosis and its associated risk factors in the emerging dairy belts of regional cities in Ethiopia. Prev. Vet. Med., 168: 81-89.

45. Fikre, Z., Gebremedhin, R., Gebretsadik, B., Gezahegne, M., Tesfaye, S. and Gobena, A. (2014) Prevalence of bovine tuberculosis and assessment of Cattle owners awareness on its public health implication in and around Mekelle, Northern Ethiopia. J. Vet. Med. Anim. Health, 6(6): 159-167.

46. Zarden, C., Marassi, C., Figueiredo, E. and Lilenbaum, W. (2013) Mycobacterium bovis detection from milk of negative skin test cows. Vet. Rec., 172(5): 130.

47. Mugizi, D.R., Muradrasoli, S., Boqvist, S., Erume, J., Nasinyama, G.W., Waiswa, C., Mboowa, G., Klint, M. and Magnusson, U. (2015) Isolation and molecular characterization of Brucella isolates in cattle milk in Uganda. Biomed Res. Int., 2015: 720413.

48. Buhari, H., Saidu, S., Mohammed, G. and Raji, M. (2015) Evidence of Brucella antibodies in milk of cows in the north senatorial District of Kaduna State, Nigeria. Res. J. Vet. Pract., 3(2): 33-35.

49. Miller, R., Nakavuma, J., Ssajjakambwe, P., Vudriko, P., Musisi, N. and Kaneene, J. (2016) The prevalence of brucellosis in cattle, goats and humans in rural Uganda: A comparative study. Transbound. Emerg. Dis., 63(6): e197-e210.

50. Al-Mariri, A. (2015) Isolation of Brucella melitensis strains from Syrian bovine milk samples. Bulg. J. Vet. Med., 18(1): 40-48.

51. Nafarnda, W., Obudu, C., Omeiza, G., Enem, S. and Adeiza, M. (2015) Prevalence of Zoonotic bovine tuberculosis and associated risk factors among cattle herds in North Central Nigeria. Int. J. Curr. Res. Acad. Rev., 3(7): 113-119.

52. Ameni, G., Bonnet, P. and Tibbo, M. (2003) A cross-sectional study of bovine tuberculosis in selected dairy farms in Ethiopia. Int. J. Appl. Res. Vet. Med., 1(4): 253-258.

53. Lobna, M.A.S. and Nasr, E.A. (2015) Conventional and molecular detection of Mycobacterium bovis in milk of cows and its public health hazard. Int. J. Adv. Res., 3: 693-701.

54. Malakalinga, J. (2015) Use of Molecular Methods to Detect Shedding of Mycobacterium bovis in Cattle Faeces and Milk: Sokoine University of Agriculture. Available from: http://www.suaire.sua.ac.tz/handle/123456789/795. Retrieved on 1712-2018.

55. Ameni, G. and Erkihun, A. (2007) Bovine tuberculosis on small-scale dairy farms in Adama Town, central Ethiopia, and farmer awareness of the disease. Rev. Sci. Tech., 26(3): 711-720.

56. Cadmus, S.I., Yakubu, M.K., Magaji, A.A., Jenkins, A.O. and Van Soolingen, D. (2010) Mycobacterium bovis, but also M. africanum present in raw milk of pastoral cattle in North-Central Nigeria. Trop. Anim. Health Prod., 42(6): 1047-1048.

57. Kahla, I.B., Boschiroli, M., Souissi, F., Cherif, N., Benzarti, M., Boukadida, J. and Hammami, S. (2011) Isolation and molecular characterisation of Mycobacterium bovis from raw milk in Tunisia. Afr. Health Sci., 11(Suppl 1): 2-5.

58. Bolaños, C.A.D., Franco, M.M.J., Filho, A.F.S., Ikuta, C.Y., Burbano-Rosero, E.M., Neto, J.S.F., Heinemann, M.B., Motta, R.G., Paula, C.L.D., Morais, A.B.C. and Guerra, S.T 
(2018) Nontuberculous mycobacteria in milk from positive cows in the intradermal comparative cervical tuberculin test: Implications for human tuberculosis infections. Rev. Inst. Med. Trop. Sao Paulo., 60: e6.

59. Nuru, A., Mamo, G., Zewude, A., Mulat, Y., Yitayew, G., Admasu, A., Medhin, G., Pieper, R. and Ameni, G. (2017) Preliminary investigation of the transmission of tuberculosis between farmers and their cattle in smallholder farms in Northwestern Ethiopia: A cross-sectional study. BMC Res. Notes, 10(1): 31 .

60. de Jong, B.C., Adetifa, I., Walther, B., Hill, P.C., Antonio, M., Ota, M. and Adegbola, R.A. (2010) Differences between TB cases infected with $M$. africanum, West-African Type 2, relative to Euro-American M. tuberculosis-an update. FEMS Immunol. Med. Microbiol., 58(1): 102.

61. Sawai, T., Inoue, Y., Doi, S., Izumikawa, K., Ohno, H., Yanagihara, K., Higashiyama, Y., Miyazaki, Y., Hirakata, Y. and Tashiro, T. (2006) A case of Mycobacterium nonchromogenicum pulmonary infection showing multiple nodular shadows in an immunocompetent patient. Diagn. Microbiol. Infect. Dis., 54(4): 311-314.
62. Lai, C.C., Chen, H.W., Liu, W.L., Ding, L.W., Lin, C.L., Lu, G.D. and Hsueh, P.R. (2008) Fatal meningitis caused by Mycobacterium nonchromogenicum in a patient with nasopharyngeal carcinoma. Clin. Infect. Dis., 46(2): 325-326.

63. Heidarieh, P., Hashemi-Shahraki, A., Khosravi, A., ZakerBoustanabad, S., Shojaei, H. and Feizabadi, M. (2013) Mycobacterium arupense infection in HIV-infected patients from Iran. Int. J. STD AIDS, 24(6): 485-487.

64. Doran, P., Carson, J., Costello, E. and More, S. (2009) An outbreak of tuberculosis affecting cattle and people on an Irish dairy farm, following the consumption of raw milk. Ir. Vet. J., 62(6): 390-397.

65. Schoder, D., Winter, P., Kareem, A., Baumgartner, W. and Wagner, M. (2003) A case of sporadic ovine mastitis caused by Listeria monocytogenes and its effect on contamination of raw milk and raw-milk cheeses produced in the on-farm dairy. J. Dairy Res., 70(4): 395-401.

66. Addis, M.F., Cubeddu, T., Pilicchi, Y., Rocca, S. and Piccinini, R. (2019) Chronic intramammary infection by Listeria monocytogenes in a clinically healthy goat-a case report. BMC Vet. Res., 15(1): 229.

$* * * * * * * *$ 